l'Université de Grenoble, a entrepris une étude géographique des Dallols Fogha et Mawri. Sous sa ditection, trois étudiants en géographie ont établi des monographies de village portant sur des aspects particuliers de l'installation humaine dans la région des Dallols.

Ader-Doutchi-Majya. Sous la direction de $\mathrm{H}$. Raulin, plusieurs études sur des projets d'aménagement ont été effectuées à la demande du gouvernement nigérien (N. Echard, P. Bonte, P. Monnier). N. Echard, anthropologue, a entrepris et poursuit l'étude fondamentale des populations Aderawa (et en particulier, au cours de ses deux dernières missions, l'étude de certains groupes de forgerons).

Hausa de l'Est. A partir de $1963, \mathrm{G}$. Nicolas, anthropologue de l'Université de Bordeaux, a étendu ses études sur l'économie hausa à la région de Maradi, où une base secondaire de recherches a été établie. Il a travaillé successivement en collaboration avec M. Mainet, géographe, et $\mathrm{H}$. Doumesche. J. Nicolas, psychologue, a étudié les problèmes de la possession chez les femmes de la région de Maradi.

Nomades. Parallèlement à l'enquête quantitative menée par le Service statistique du Niger et du Ministère français de la Coopération, M. Dupire, anthropologue, et E. Bernus, géographe, ont poursuivi leurs travaux, la première sur les aspects socio-démographiques (recueil de généalogies chez les Peuls Bororo), le second sur les différents aspects de la vie pastorale dans le Sahel nigérien, en particulier chez les populations de langue tamasheq.

Problèmes urbains. S. Bernus, anthropologue, s'est attachée à l'étude des particularismes ethniques en milieu urbain. L. F. van Hoy, sociologue (Northwestern University), au cours d'un séjour de six mois, s'est intéressé aux problèmes des associations à Niamey et a entrepris deux études sur Maradi et Zinder.

Linguistique. Divers linguistes ont effectué des missions de durée variable au sein des principaux groupes linguistiques: C. Gouffé, professeur de hausa à l'École des Langues orientales (dialectes du Gobir); P. Lacroix, professeur de fulfuldé à l'École des Langues orientales, s'intéresse également à la tadahusahak (langue mixte Songhay-Tamasheq); L. Galand, professeur de berbère à l'École des Langues orientales (dialectes tamasheq). Ces missions avaient à la fois pour objet une étude théorique des langues précitées et l'établissement d'un mode simple de transcription en vue de l'alphabétisation des adultes (sous les auspices de l'U.N.E.S.C.O.).

Dans le domaine des recherches historiques, le travail s'est borné, au cours des dernières années, à un inventaire des Archives de Niamey.

\title{
Rapports et Thèses
}

A la demande expresse du gouvernement du Niger, ces études ont donné lieu à la préparation et à la diffusion restreinte de rapports provisoires (série Études nigériennes ou Documents des Études nigériennes):

I. In Memoriam Ch. Lecceur (épuisé).

2. Y. URvoY: L'art dans le territoire du Niger.

3. M. Dupire: La place du commerce et des marchés dans l'économie des Bororo nomades au Niger (épuisé).

4. S. Vianes: Migrations en Afrique de l'Ouest: Mouvements de marchandises au Ghana (épuisé).

5. H. RAULIN: Rapport provisoire, remplacé par le $\mathrm{n}^{\circ}{ }_{2}$ (épuisé).

6. M. Duprre: Les facteurs humains de l'économie pastorale (épuisé).

7. J. Nicolarsen: Structures politiques et sociales des Touareg de l'Airr et de l'A haggar (épuisé).

8. G. Nicolas: Notes ethnographiques sur le terroir, l'agriculture et l'élevage dans la vallée de Maradi (épuisé).

9. E. Bernus: Quelques aspects de l'évolution des Touareg de l'Ouest (épuisé).

Io. C. Piault: Contribution à l'étude de la vie quotidienne de la femme Maouri.

II. S. Bernus: Niamey, population et habitat. 
12. H. Raulin: Techniques et bases socio-économiques des sociétés rurales nigériennes.

13. M. H. Piault: Populations de l'Arewa (épuisé).

I4. H. Raulin: Enquête socio-économique rurale, $1961-1963$ (épuisé).

I 5. N. Echard: Étude socio-économique dans les vallées de l'Ader Doutchi-Majya (épuisé).

i6. G. Matnet-G. Nicolas: La vallée du Gulbi de Maradi.

17. P. David: La geste du grand K’Aura Assao (épuisé).

18. P. David: Maradi, l'ancien état et l'ancienne ville. Site, population, histoire (épuisé).

19. R. Rochetre: Doumega, Dioundiou, Kawara Débé, villages des Dallols Maouri et Fogha.

A paraître:

20. J. P. Olivier de Sardan: Les Wogo du Niger.

Thèses de zème cycle présentées:

H. Raulin: La dynamique des techniques agraires en Afrique tropicale du Nord.

G. NicolAs: La circulation des richesses dans une société haoussa: Kantché.

M. H. Prault: Histoire Mauri - introduction à l'étude des processus constitutifs d'un État.

S. Bernus: Particularismes ethniques en milieu urbain: l'exemple de Niamey.

\section{Films}

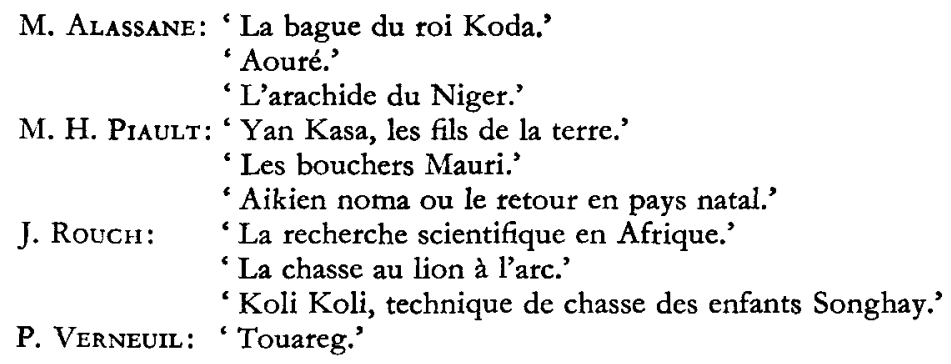

(Communication de M. Edmond Bernus)

\section{University of the Witwatersrand: African Studies Programme 1967}

The African Studies Programme of the University of the Witwatersrand was established in 1964 , and courses were first offered in 1965 . It aims to bring together scholars from different disciplines who share a common interest in African studies, and to co-ordinate some of their teaching and research activities; to offer courses leading to a diploma or an honours degree in African studies; to hold regular seminars, to sponsor research projects, and to publish the results of these investigations as far as possible. The emphasis of the programme is on interdisciplinary work throughout.

For rural sociologists, and for anthropologists interested in traditional African cultures, there are country towns and predominantly peasant communities within easy each of Johannesburg. For archaeologists, there are the remains of prehistoric Iron Age communities awaiting excavation. Ethnomusicologists can study traditional African music and dancing in a new setting on the mines, or modern African jazz and 'urban folk music' in the townships. In Johannesburg and its environs can be found native speakers of dozens of African languages from as far afield as Angola, Zambia, Malawi, and Tanzania. There is an ethnological museum containing, in particular, specimens from the Luba, Bemba, Ovambo, Venda, Pedi, Zulu, and Bushmen. Unique archaeological and palaeontological material is housed on the University campus, and there are also fine collections of books and ethnographic specimens in the Johannesburg Public Library. The University has a collection of 